\title{
Regional Economic Disparities in Australia
}

\author{
Uma Ramakrishnan and Martin Cerisola
}




\title{
IMF Working Paper
}

Asia and Pacific Department

\section{Regional Economic Disparities in Australia}

Prepared by Uma Ramakrishnan and Martin Cerisola ${ }^{1}$

Authorized for distribution by Steven Dunaway

August 2004

\begin{abstract}
This Working Paper should not be reported as representing the views of the IMF. The views expressed in this Working Paper are those of the author(s) and do not necessarily represent those of the IMF or IMF policy. Working Papers describe research in progress by the author(s) and are published to elicit comments and to further debate.

Australia's remarkable economic performance during the 1990s has not resulted in a significant convergence of real per capita income, output, and employment levels across the country's states and territories. This paper explores the role of certain economic rigidities that may have contributed to the lack of convergence, including rigidities in labor markets and in the structure of federal government transfers to households and subnational governments. The analysis suggests that the wage awards system has restricted the adjustment of real wages to productivity differentials, thus contributing to higher unemployment rates in some states. Federal government transfers to households also appear to have adversely affected work incentives in high unemployment states by limiting participation in the labor force.
\end{abstract}

JEL Classification Numbers: H7, J5, R1

Keywords: Regional disparities, wage bargaining, government transfers

Author’s E-Mail Address: uramakrishnan@imf.org; mcerisola@imf.org

\footnotetext{
${ }^{1}$ We would like to thank Steven Dunaway, Jim Gordon, Roberto Cardarelli, and Greg Coombs (Australian Treasury) for their useful comments. Any errors remain our own.
} 


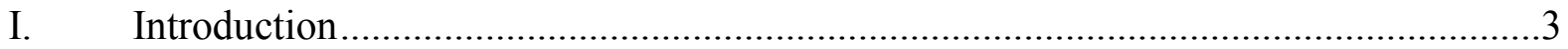

II. Stylized Facts on Australia’s Regional Disparities..............................................4

III. Factors Contributing to Regional Disparities ...................................................

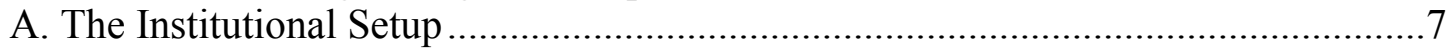

B. Some Empirical Evidence ..........................................................................

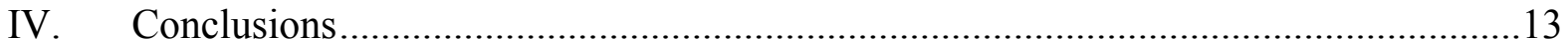

Annex

Variables: Definitions and Sources..............................................................21

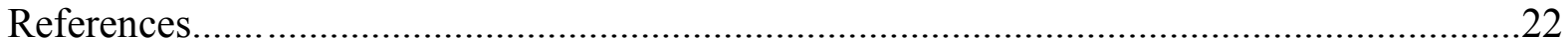

Boxes

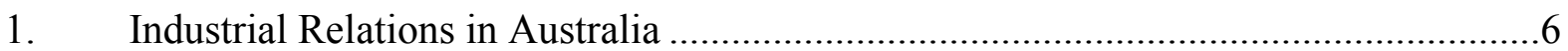

2. Overview of the Current System of Intergovernmental Transfers............................11

Figures

1. Ratio of Real Per Capita State Disposable Income to the Average

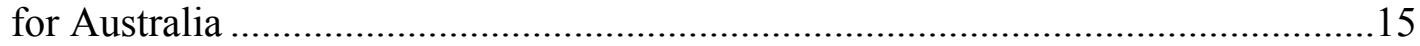

2. Ratio of Real Per Capita State Output to the Average for Australia .........................16

3. Dispersion of Per Capita State Output and Household Income ................................17

4. Dispersion in the Unemployment Rate and Median Duration of Unemployment.......18

5. Median Duration of Unemployment by State ......................................................... 18

6. Long-Term Unemployment Rate by State.........................................................19

7. Employment to Population Ratio in Australia States ............................................20

Tables

1. Summary Indicators on State Output, and Income, 1990-01 ..................................4

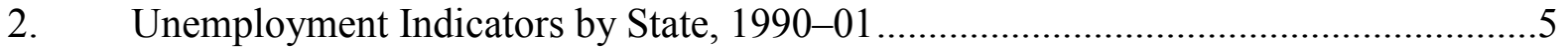

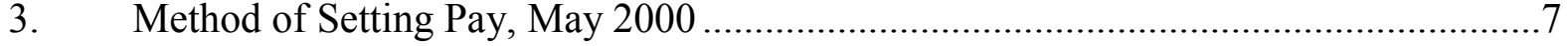

4. Ratio of Real Government Transfers Per Household to the Australian Average .........8

5. Estimation Results: Labor Market Equation................................................... 10

6. Estimation Results: Income Growth Equation...................................................... 14

7. Estimation Results: Output Growth Equation.................................................. 14 


\section{INTRODUCTION}

A vast amount of theoretical and empirical research suggests that per capita income and output across regions in a country should converge over time as resources get reallocated based on regional comparative advantages (Quah, 1995; and Kim, 1997). In Australia, however, the comprehensive economic reforms undertaken since the mid-1980s have not brought significant convergence in real per capita income and output across the states during the 1990s. ${ }^{2}$ Moreover, a pattern of regional unemployment has persisted, with unemployment rates being consistently higher than the national average in those states with lower than average real per capita income and output. ${ }^{3}$

This paper provides an empirical analysis of the factors that may have impeded convergence across states, particularly those states with relatively lower real per capita income/output. Likely suspects are rigidities in labor markets and government transfers. In fact, some government transfers, such as, payments to persons are likely to have mitigated part of the divergence in real per capita incomes across states, but other transfers may have contributed to part of the gaps in real per capita output and unemployment. Transfers to state governments based on the principle of "equalization, that is, trying to "equalize" fiscal resources to ensure that a minimum standard of public services can be provided by subnational governments across the country may have created some disincentives that could have adversely affected real per capita income/output and unemployment. In the same vein, there is the possibility that structural reforms to the economy paved the way for increased adoption of new technologies that may have spurred faster growth in real per capita income and output growth in higher relative to lower income states. ${ }^{4}$

The empirical results presented in this paper are based on panel estimation, and suggest that the wage awards system may have restricted the adjustment of real wages to productivity differentials and contributed to higher unemployment rates in some states. ${ }^{5}$ Government

\footnotetext{
2 "States" refers to the six Australian states and two territories (see Table 1).

${ }^{3}$ While regional disparities no doubt are a significant issue for Australia, the problem is far less entrenched than in some other countries such as China, the United States, and Canada (Garnaut and FitzGerald, 2002; and Kaufman and others, 2003).

${ }^{4}$ Other factors not considered here may also have contributed to the regional disparities. For example, industry composition and diversification of a state relative to the national economy, the proximity of a region to product and factor markets, and physical and cultural amenities of a specific region could influence regional employment and output (Lawson and Dwyer, 2002).

${ }^{5}$ The sample period underlying the analysis is from 1990 to 2001 . If the sample period was sufficiently extended, the results may indicate convergence among the regions. For example, Cashin (1995) shows that there has been convergence in real per capita GDP across the colonial economies of Australasia during the period 1861-1991.
} 
transfers to households also appear to have adversely affected work incentives in high unemployment states by limiting participation in the labor force. The results suggest that growth in the relatively low-income and output states to some extent converged during the 1990s toward that in higher income states, but the initial differences in per capita income and output across the states largely remained. Since 1997, however, the catch-up effect on output growth has slowed down, and the impact on real per capita income growth across states of government transfers appears to have increased. The results also suggest that federal grants to the states did not have a significant impact on output growth across states in the 1990s, and that the impact of skill-biased technological change on real per capita income and output growth is not clear.

\section{Stylized Facts on Australia’s Regional Disparities}

Analysis of the disparities in real per capita output and disposable income suggests that Australian states can be divided into two groups: one group in which the real per capita output and income are higher than the national average (consisting of New South Wales, Victoria, Western Australia, the Northern Territory, and the Australian Capital Territory (ACT)), and another group with output and income levels below the national average (comprising Queensland, South Australia, and Tasmania) (Figures 1 and 2 and Table 1). ${ }^{6}$ The cross-state dispersion in output and income variables has increased from the mid-1990s, with the dispersion in output far higher than in disposable income (Figure 3$)^{7}$

\begin{tabular}{|c|c|c|c|c|c|c|c|}
\hline \multicolumn{8}{|c|}{$\begin{array}{l}\text { Table 1. Summary Indicators on State Output and Income, 1990-01 } \\
\text { (In percent) }\end{array}$} \\
\hline & \multirow[t]{2}{*}{$\begin{array}{l}\text { Real per Capita } \\
\text { Avg. GDP Growth }\end{array}$} & \multicolumn{3}{|c|}{$\begin{array}{l}\text { Ratio to Australian } \\
\text { Real per Capita GDP }\end{array}$} & \multicolumn{3}{|c|}{$\begin{array}{l}\text { Ratio to Australian Real per Capita } \\
\text { Household Disposable Income 1/ }\end{array}$} \\
\hline & & 1990 & 1995 & 2001 & 1990 & 1995 & 2001 \\
\hline New South Wales & 2.2 & 104.5 & 104.8 & 106.9 & 106.8 & 105.7 & 107.4 \\
\hline Victoria & 2.1 & 102.2 & 99.9 & 102.9 & 101.7 & 99.8 & 103.7 \\
\hline Queensland & 2.1 & 85.7 & 87.3 & 86.7 & 84.3 & 86.3 & 89.0 \\
\hline South Australia & 1.4 & 89.5 & 84.7 & 83.4 & 93.3 & 91.8 & 88.7 \\
\hline Western Australia & 2.1 & 106.7 & 115.3 & 107.8 & 95.5 & 102.1 & 94.0 \\
\hline Tasmania & 1.2 & 79.2 & 77.6 & 72.0 & 86.1 & 85.4 & 81.2 \\
\hline Northern Territory & 1.4 & 128.0 & 120.4 & 119.1 & 102.2 & 111.9 & 97.0 \\
\hline ACT & 1.9 & 127.2 & 123.9 & 125.9 & 145.1 & 144.0 & 135.1 \\
\hline
\end{tabular}

\footnotetext{
${ }^{6}$ While there are many studies pointing to this issue (Harris and Harris, 1992; Cashin, 1995; Cashin and Strappazzon, 1998; and Neri, 1998), only a few studies (including Debelle and Vickery, 1999; and Lawson and Dwyer, 2002) consider possible reasons for these disparities, and they focus mostly on labor market outcomes.

${ }^{7}$ Dispersion is measured in Figure 3 as the coefficient of variation, which is the standard deviation across the states divided by the mean.
} 
However, closer examination of the data indicates that the income dispersion is largely influenced by the income pattern in the ACT. Without the ACT, income dispersion across states is lower and more or less unchanged during the 1990s. At the same time, the gap between output and income dispersion has increased, suggesting that transfers have had a large impact in narrowing income inequalities. Output dispersion across states is only slightly lower excluding the ACT, and it rises after 1997. The output dispersion seems to have risen during a period when significant economic reforms in Australia began to take hold. Since the early 1990s, a number of microeconomic reforms in transport infrastructure, utilities industry, and telecommunications were implemented across Australia. Significant labor market reforms were also initiated in 1996 with the enactment of the Workplace Relations Act (Box 1).

Large disparities also exist in regional unemployment rates and the median duration of unemployment across states (Figure 4 and Table 2). The unemployment rate and the median duration of unemployment are higher in those states with below average income and output. In 2001, South Australia and Tasmania had a median unemployment duration of 25 and 35 weeks, respectively, compared with the national average of 18 weeks (Figure 5). Further, long term unemployment rates in the lower income states are significantly higher than the Australian average (Figure 6). The variability among states of the ratio of employment to population also follows a pattern similar to those for income and output for the two groups of states (Figure 7).

\begin{tabular}{|l|ccc|ccc|}
\hline \multicolumn{7}{|c|}{ Table 2. Unemployment Indicators by State, 1990-01 } \\
\hline & \multicolumn{3}{|c|}{$\begin{array}{c}\text { Unemployment Rate } \\
\text { (In percent) }\end{array}$} & \multicolumn{3}{c|}{$\begin{array}{c}\text { Median Duration of Unemployment } \\
\text { (In weeks) }\end{array}$} \\
\cline { 2 - 7 } & 1990 & 1995 & 2001 & 1990 & 1995 & 2001 \\
\hline New South Wales & 6.1 & 6.7 & 5.4 & 20.1 & 32.7 & 18.3 \\
Victoria & 5.8 & 8.7 & 6.3 & 12.6 & 34.6 & 17.8 \\
Queensland & 6.7 & 8.7 & 8.3 & 13.8 & 20.9 & 17.0 \\
South Australia & 7.3 & 9.4 & 7.2 & 25.5 & 36.1 & 25.0 \\
Western Australia & 7.5 & 7.2 & 6.8 & 8.8 & 19.8 & 12.9 \\
Tasmania & 8.5 & 9.7 & 8.8 & 28.2 & 39.7 & 35.1 \\
Northern Territory & 7.0 & 7.3 & 6.8 & 12.9 & 15.6 & 11.1 \\
ACT & 5.3 & 6.8 & 4.9 & 12.4 & 19.3 & 15.0 \\
Australia & 6.7 & 8.2 & 6.7 & 16.3 & 28.6 & 18.0 \\
\hline
\end{tabular}




\section{Box 1: Industrial Relations in Australia}

Prior to the labor market reforms introduced in 1996, the main feature of Australia's labor relations system was the long-established quasi-judicial system of conciliation and arbitration based on federal and state tribunals. Conciliation and arbitration played a larger role in setting the terms and conditions of the workplace (called "awards") than independent collective bargaining. In 1990, federal and state awards covered about two-thirds of Australian wage and salary earners.

Awards are legally enforceable contracts, and generally apply to whole industries, occupations, or crafts. Both federal and state awards regulate a number of work conditions, including wage rates, job classifications, and hours of work, and are meant to provide only the "minimum conditions". Employees can also negotiate with their employers "over-award" payments above these minima. Awards usually bind both union and non-union employees. Although the award system has been responsible for setting the minimum wage standards and reduced the costs of collective bargaining, its main disadvantage is that it reduces flexibility at the firm level, contributing to lower productivity growth by not providing adequate incentives for improving the skill level.

Recognizing the obstacle that the centralized wage bargaining system posed to labor market flexibility, the federal government introduced the Workplace Relations Act in 1996 to facilitate the transition of workplace relations framework from the centrally determined awards system to bargaining at the workplace and enterprises to determine the actual pay. Two types of certified agreements are provided under the Act - those reached directly with employees and those reached between employers and unions. Certified agreements still require that an employee is no worse off than compared with the terms and conditions of the relevant award. The role of awards has also been restricted to setting a true safety net, with the number of "allowable matters" reduced to 20 and all other matters being determined at the workplace level. The award coverage has fallen significantly from nearly two-thirds of employees in 1990 to 21 percent in 2001.

State governments have introduced similar reforms to their industrial relations systems. The most dramatic shift came from Victoria, which simply transferred its state industrial relations system to the federal system in 1996. Other states have retained their separate systems, thus posing a continuing problem because of the co-existence of overlapping laws and regulations, tribunals, and awards between the federal and state systems in a single workplace. 


\section{Factors Contributing to Regional Disparities}

\section{A. The Institutional Setup}

Centralized wage bargaining could be an important factor contributing to labor market rigidities in Australia. The Workplace Relations Act of 1996 has facilitated the transition of the industrial relations system from a centrally determined wage awards system to enterprise bargaining. In the current system, the role of awards has been restricted to setting a safety net of minimum wages and conditions. Although award coverage has declined substantially since 1990, the award-based wage setting is still substantial — more so in the lower income states, where the share of employees subject to minimum wages is higher (Table 3 ). With a substantial proportion of wages, particularly at the low end of the pay scale, still based only on awards, employers continue to have less room to adjust for productivity differentials. ${ }^{8}$ Under the award system, wages across states cannot reflect regional productivity differences, causing unemployment to be above average in those areas with below average productivity.

\begin{tabular}{|l|c|c|c|}
\hline \multicolumn{4}{|c|}{ Table 3. Method of Setting Pay, May 2000 } \\
(Percent of Employees) \\
\hline & Awards & Collective & Individual \\
& Only & Agreement & Agreement \\
\hline New South Wales & 23.9 & 34.4 & 41.7 \\
Victoria & 21.1 & 34.0 & 45.0 \\
Queensland & 24.6 & 41.8 & 33.6 \\
South Australia & 30.5 & 38.7 & 30.8 \\
Western Australia & 18.3 & 35.3 & 46.4 \\
Tasmania & 32.2 & 42.2 & 25.6 \\
Northern Territory & 24.4 & 41.5 & 34.1 \\
ACT & 16.2 & 59.4 & 24.4 \\
Australia & 23.2 & 36.8 & 40.0 \\
\hline Source: Australian Bureau of Statistics Catalog No. 6306. \\
\hline \multicolumn{4}{|l}{} \\
\hline
\end{tabular}

\footnotetext{
${ }^{8}$ The actual proportion of employees subject to only awards in setting wages varies by sector, industry, and enterprise size. For instance, 65 percent of the recreational industry is covered by awards only, compared with less than 6 percent of mining and finance and insurance sectors. Forty-two percent of clerical, sales, and service workers are covered by awards, compared with 3 percent of managers and administrators.
} 
Government transfers per household are higher for states that have the largest output and unemployment gaps with the rest of Australia (Table 4). ${ }^{9}$ Government programs to provide income support may have unintended adverse economic consequences, particularly on incentives for lower-skilled workers. The current evidence is mixed in this regard. The Industry Commission (1993) notes that income support payments can undermine work incentives for those already prone to long term unemployment. Also, uniformity in benefits across states suggests that people may have some incentive to migrate from low to high unemployment regions with lower costs of living. ${ }^{10}$ Studies by Debelle and Vickery (1999) and Lawson and Dwyer (2002), however, find that migration is an important channel for adjustment to labor market shocks, and that out migration has been characteristic of states with higher unemployment rates.

\begin{tabular}{|l|l|c|}
\hline \multicolumn{4}{|c|}{ Table 4. Ratio of Real Government Transfers Per Household } \\
to the Australian Average \\
(In percent)
\end{tabular}

The "equalization" aspect of the current arrangements for federal grants to the states can be viewed as potentially creating some disincentive for state governments to introduce changes designed to enhance growth prospects (Craig, 1997). ${ }^{11}$ A portion of the federal government

${ }^{9}$ The data on government transfers include workers compensation and various social assistance payments, but excludes old age pension. See the data annex for details.

${ }^{10}$ According to the Commission's report, the Social Security Act has a provision to discourage migration to areas with lower employment prospects, but enforcement is characterized as being lax. While the law was intended to apply to all persons who reduced their employment prospects by migrating, the penalty is generally applied only to those already receiving benefits.

${ }^{11}$ Box 2 provides an overview of the current system for Commonwealth-State funding and its limitations. A study was commissioned by the governments of New South Wales, Victoria, and Western Australia to review the methods of allocating Commonwealth grants to the states and territories, and the appropriateness of the outcomes. See Garnaut and FitzGerald (2001 and 2002). Meanwhile, the Ministerial Council on Commonwealth State Financial Relations is also considering a review of the methodology (see Australian Government, 2004). 
grants are allocated to the states on the basis of each state's ability to generate its own-source revenue in an attempt to at least partially equalize revenue across states, so that each state has sufficient resources to provide a minimum standard of public services. Hence, if a policy change improves a state's revenue, and the state is assessed as having above average capacity, then federal grants would decline, partially offsetting the revenue gain. Consequently, this grants arrangement may impede actions which would boost the real per capita income and output levels of the lower income states. ${ }^{12}$

\section{B. Some Empirical Evidence}

\section{Labor market}

In explaining the dispersion of unemployment across states, the following pooled regression (with fixed effects) was estimated to assess the importance of the wage determination system and government transfers to households:

$\mathrm{UR}_{\mathrm{i}, \mathrm{t}}=\beta_{0 \mathrm{i}}+\beta_{1}(\mathrm{PWGAP})_{\mathrm{i},(\mathrm{t}-1)}+\beta_{2}(\text { TRANSFER })_{\mathrm{i}, \mathrm{t}}+\beta_{3} \mathrm{UR}_{\mathrm{i}, \mathrm{t} \mathrm{t}-1)}+\varepsilon_{\mathrm{i}, \mathrm{t}}$

UR is the unemployment rate in state i relative to the national average, PWGAP is the differential between productivity and real wages in state i relative to the national level, and is indicative of the influence of wage-setting arrangements, while TRANSFER is real government transfers per labor force participant in state i relative to the national average. ${ }^{13}$ While contemporaneous information on the government transfer variable is usually available to labor force participants in making their work-leisure decisions, the labor productivity-wage gap variable is likely to impact the unemployment rate with a lag; the lagged dependent variable controls for any persistence or hysteresis component in unemployment.

The estimation results show that the unemployment rate is higher when real wages in a state are high relative to the state's productivity (Table 5). However, the government transfers variable does not have the expected sign - a priori, one expects that as relative transfers to a state increase, the incentives to work in the state decline and cause higher unemployment. The counter-intuitive result could be because transfers tend to lower work incentives and efforts to

12 This situation is roughly comparable to that faced by welfare recipients who confront high effective marginal income tax rates owing to the withdrawal of benefits when they return to work.

${ }^{13}$ Due to data limitations on the components of social assistance at the state level, old age pensions are subtracted from the transfer data by applying the ratio of old age pensions to total social assistance at the Commonwealth government level to the state level data. This implicitly assumes that the ratio of old age transfers across all states are the same, which obviously may not be the case. The Annex provides further detailed data definitions. 
seek jobs, thus keeping people out of the labor force (i.e., reducing participation rates), which in turn serves to keep the unemployment rate down.

To allow for this possibility, an alternative equation was estimated regressing the employment to population ratio on the productivity-wage gap and government transfers. This equation shows that both the labor market and government transfer variables have the expected signs and are highly significant. The results suggest that states with above average government transfers tend to have lower employment to population ratios, implying that these transfers constrain work incentives and participation in the labor market.

The employment-population ratio could also be higher in states with a higher concentration of skilled labor. The states that adopted the technological advancements of the 1990s more rapidly than others are likely to have experienced a higher demand for skilled labor. Adding an index for skill levels by state relative to the average for Australia to the equation confirms that the employment-population ratio rises as the relative skill level of a state increases relative to the national average.

\begin{tabular}{|l|l|c|c|}
\hline \multicolumn{3}{|c|}{ Table 5. Estimation Results: Labor Market Equation } \\
\hline Dependent Variable & Independent Variables & $\beta$-coefficient & P-value 1/ \\
\hline Unemployment ratio & Productivity-wage gap(-1) & -12.441 & 0.005 \\
& Transfers per labor force participant & -0.430 & 0.862 \\
& Unemployment ratio(-1) & 0.652 & 0.000 \\
& Adjusted R-squared & 0.835 & \\
\hline Employment/Population 2/ & Productivity-wage gap(-1) & 0.107 & 0.000 \\
& Transfers per labor force participant & -0.087 & 0.000 \\
& Employment/Population (-1) & 0.646 & 0.000 \\
& Skill bias & 0.005 & 0.061 \\
\hline & Adjusted R-squared & 0.878 & \\
\hline $\begin{array}{l}\text { Note: Results for pooled estimation with fixed effects; fixed effects are small and not presented here. } \\
\text { 1/ P-values are the probability values for the null hypothesis of a coefficient equal to zero. Thus, a value } \\
\text { of .005, for example, indicates coefficient significance at less than one percent level. } \\
\text { 2/ Estimation excludes Australian Capital Territory for which skill bias data are not available. }\end{array}$ \\
\hline
\end{tabular}




\section{Box 2. Overview of the Current System of Intergovernmental Transfers ${ }^{1}$}

States and territories rely heavily on Commonwealth funding. In 2001/02, Commonwealth grants to states included about \$A30 billion of General Purpose Payments (untied grants) and some \$A20 billion of Special Purpose Payments (tied grants, for specific purposes such as health, education, roads, and housing). There is an underlying inter-governmental agreement between the Commonwealth and the states. The heavy reliance of states on the Commonwealth is due to the dominance of the Commonwealth in tax collection, while the responsibility of delivery of important services is at the state level, thus creating a "vertical gap" for state governments in terms of revenue collection and expenditure responsibilities.

The Commonwealth Grants Commission's (CGC) horizontal fiscal equalization principle aims to give each state the same capacity to provide services. While the horizontal fiscal equalization has existed from the 1930s with some modifications over time, the CGC's interpretation of the principle has shifted from one of "rough parity" to a formal requirement of achieving "absolute equality" of capacity among states. For this, the CGC provides funding to states such that if each state made the same effort to raise revenue from its own resources and operated at the same level of efficiency, each would have the capacity to provide the same level and standard of service. Thus, a greater share of grants go to states with below average capacity to raise their own revenues and/or need to spend more to provide the same standard of services as other states.

The appropriateness of the equalization principle has come under close scrutiny on both equity and efficiency grounds. It has been suggested that allocation of federal money to states should increase incentives for states to improve their performance. This relates to the "policy neutrality" objective of the fiscal equalization principle, which aims to avoid situations wherein states can influence the amount of grants they receive through their policies. However, some view the CGC methodology as not being policy neutral, and that states can, in the long term, influence their need for services and/or the health of their economy and their revenue raising capacity.

Some consider the current system not to be very efficient - according to Garnaut and FitzGerald (2002), it creates a deadweight loss to the tune of about \$200 million per year, which arises primarily from high overheads and other transaction costs of administering the system. Additionally, the system is neither simple nor transparent, and often judgmental, and is not well understood beyond those involved. However, there is no consensus on the efficiency issue. Other studies (Buchanan and Wagner, 1971 and Mathews, 1983) have argued that the Australian intergovernmental transfer system has been effective and achieved considerable success in contributing to fiscal equalization.

${ }^{1}$ Draws from Garnaut and FitzGerald $(2001,2002)$. These studies which were commissioned by the governments of New South Wales, Victoria, and Western Australia. 


\section{Income and Output Growth}

Empirical analysis of the possible causes for the lack of convergence in regional incomes and outputs is based on the following equations:

Income growth equation: $(\mathrm{DIG})_{\mathrm{i}, \mathrm{t}}=\beta_{0 \mathrm{i}}+\beta_{1}(\mathrm{DI})_{\mathrm{i}, \mathrm{t} \mathrm{t}-1)}+\beta_{2}(\mathrm{TRANSFER})_{\mathrm{i}, \mathrm{t}}+\beta_{3}(\mathrm{SKILL})_{\mathrm{i}, \mathrm{t}}+\varepsilon_{\mathrm{i}, \mathrm{t}}$

Output growth equation: $(\mathrm{GSPG})_{\mathrm{i}, \mathrm{t}}=\beta_{0 \mathrm{i}}+\beta_{1}(\mathrm{GSP})_{\mathrm{i}, \mathrm{t}-1)}+\beta_{2}(\mathrm{LG})_{\mathrm{i}, \mathrm{t}}+\beta_{3}(\mathrm{KG})_{\mathrm{i}, \mathrm{t}}+$

$$
\beta_{4}(\text { TRANSFER })_{i, t}+\beta_{5}(\text { GPP })_{i, t}+\beta_{6}(\text { SKILL })_{i, t}+\varepsilon_{i, t}
$$

where DIG is growth in real per capita disposable income in state i relative to the Australian average. TRANSFER is as defined above. SKILL is a proxy for skill biased growth - as human capital levels rise in certain regions, those regions tend to grow more rapidly over the long run. GSPG is growth in real per capita gross state product in state i relative to the average for Australia. LG is growth in labor force. KG is growth in real capital per capita (or real per capita investment). GPP is the ratio of real per capita general purpose payment grants to state $i$ to the Australian average. ${ }^{14}$ The lagged variables DI and GSP represent the "catch-up" effect in real per capita income and output growth of state i to the Australian average. The Commonwealth's general purpose grants to states and household transfer variables are introduced to empirically examine their impact on output growth. ${ }^{15}$

Results for the income and output equations in Tables 6 and 7 show that there is convergence in growth rates although most of the initial level differences between states are preserved (consistent with the dispersion of these two variables across states). States with lower income and output tend to grow faster as suggested by the negative estimate of the lagged income and output variables. For the output equation, the catch-up coefficient in a regression over the subsample period 1997-2001 is about half the size of the coefficient for the estimation over the subsample period 1991-1996, which is consistent with the increase in output dispersion recorded since $1997 .{ }^{16}$ The results also suggest that government transfers have helped to reduce income disparities across states. However, it appears that these transfers may have also constrained or delayed convergence in output growth across states, which could partly be reflecting its adverse effect on incentives to work.

The results indicate that relative labor force growth and capital accumulation explain most of the states' output growth. However, labor turns out to be insignificant and having the wrong

\footnotetext{
${ }^{14}$ Note that for the income equation, the income and government transfer variables are normalized per household because the disposable income data are on a household basis.

${ }^{15}$ Government general purpose grants to states are not added to the income equation since these grants are inter-governmental budgetary transfers and not direct payments to households.

16 The sample split in 1997 partly reflects the labor market reforms introduced around that time.
} 
sign in the regression for the sub-sample period 1997-2001. This could be because technological advances in the second half of the 1990s, which have contributed to substantial increases in productivity, are not accounted for. ${ }^{17}$ However, the relative skill bias coefficient in the regression over the 1997-2001 sub-sample is positive, although insignificant, suggesting that a higher skill bias (which is also indicative of technological advancement in that state) implies higher output growth.

The results also suggest that the equalization principle underlying the current federal-state funding arrangement may not be significantly contributing to creating perverse incentives among the states for output growth. The general purpose payments coefficient is negative suggesting that it adversely affected output growth, although the coefficients are statistically insignificant in two out of the three regressions. ${ }^{18}$

\section{CONCLUSIONS}

The economic reforms of the last two decades have not brought about significant convergence in real per capita income and output across Australian states; differences in regional unemployment have also persisted. This paper has provided an empirical analysis of the factors that may have impeded convergence across states. Labor market rigidities, government transfers to households and state governments, and increased adoption of new technologies in some states relative to others were considered as potential contributors to the regional disparities.

The results, based on a panel regression framework, suggest that the wage awards system may have impeded the adjustment of real wages to productivity differentials and contributed to higher unemployment rates in some states. Government transfers to households also may have adversely affected work incentives in high unemployment states by limiting participation in the labor force. However, federal grants to the states do not appear to have had a significant impact on output growth across states, and that the impact of skill-biased technological change on real per capita income and output growth is not clear.

\footnotetext{
${ }^{17}$ For the impact of technology on labor productivity, see "Is Australia a "New Economy?" in Australia: Selected Issues, IMF Staff Country Report No. 01/55, April 2001.

18 The impact of grants on growth could be narrowed down by estimating the impact of real per capita National Competition Policy Payments (NCPP) to the states. The results of the estimation of the output equation with NCPP (for the subsample from 1997-01) does not alter the above story - the NCPP remains an insignificant determinant of regional growth differentials.
} 


\begin{tabular}{|l|c|c|c|}
\hline \multicolumn{3}{|c|}{ Table 6. Estimation Results: Income Growth Equation 1/ } \\
Dependent Variable: Growth in Per Household Disposable Income \\
\hline \multirow{3}{*}{ Independent variables } & \multicolumn{3}{|c|}{$\beta$-coefficient 2/ } \\
\hline Per capita disposable income (-1) & -0.265 & $1991-96$ & $1997-01$ \\
& $(0.004)$ & -0.552 & -0.704 \\
\hline Real govt. transfers per household & 0.451 & $(0.002)$ & $(0.000)$ \\
\hline Skill bias & $(0.000)$ & 0.394 & 0.766 \\
& 0.013 & $(0.027)$ & $(0.000)$ \\
\hline Adjusted R-squared & $(0.361)$ & 0.043 & -0.014 \\
\hline Degrees of Freedom & 0.374 & $0.042)$ & $(0.279)$ \\
\hline $\begin{array}{l}\text { Note: Results for pooled estimation with fixed effects; fixed effects are small and not presented here. } \\
\text { 1/ Estimation excludes Australian Capital Territory for which skill bias data are not available. } \\
\text { 2/ P-values for the null hypothesis of a coefficient equal to zero are within parentheses. }\end{array}$ \\
\hline
\end{tabular}

\begin{tabular}{|c|c|c|c|}
\hline \multicolumn{4}{|c|}{$\begin{array}{l}\text { Table 7. Estimation Results: Output Growth Equation 1/ } \\
\text { Dependent Variable: Growth in Per Capita Gross State Product }\end{array}$} \\
\hline \multirow[b]{2}{*}{ Independent variables } & \multicolumn{3}{|c|}{$\beta$-coefficient 2/ } \\
\hline & $1991-01$ & $1991-96$ & 1997001 \\
\hline Per capita GSP ratio(-1) & $\begin{array}{l}-0.307 \\
(0.000)\end{array}$ & $\begin{array}{l}-0.512 \\
(0.000)\end{array}$ & $\begin{array}{l}-0.270 \\
(0.074)\end{array}$ \\
\hline Labor growth & $\begin{array}{c}0.366 \\
(0.007)\end{array}$ & $\begin{array}{c}0.508 \\
(0.000)\end{array}$ & $\begin{array}{l}-0.155 \\
(0.487)\end{array}$ \\
\hline Investment per capita & $\begin{array}{c}0.063 \\
(0.000)\end{array}$ & $\begin{array}{c}0.030 \\
(0.492)\end{array}$ & $\begin{array}{c}0.083 \\
(0.000) \\
\end{array}$ \\
\hline GPP ratio & $\begin{array}{l}-0.001 \\
(0.920)\end{array}$ & $\begin{array}{l}-0.025 \\
(0.637)\end{array}$ & $\begin{array}{l}-0.051 \\
(0.022)\end{array}$ \\
\hline Real govt. transfers per capita & $\begin{array}{l}-0.080 \\
(0.189) \\
\end{array}$ & $\begin{array}{l}-0.311 \\
(0.000)\end{array}$ & $\begin{array}{c}0.053 \\
(0.655)\end{array}$ \\
\hline Skill bias & $\begin{array}{l}-0.002 \\
(0.765)\end{array}$ & $\begin{array}{c}-0.021 \\
(0.139) \\
\end{array}$ & $\begin{array}{c}0.004 \\
(0.734) \\
\end{array}$ \\
\hline Adjusted R-squared & 0.333 & 0.537 & 0.470 \\
\hline Degrees of Freedom & 64 & 29 & 22 \\
\hline \multicolumn{4}{|c|}{$\begin{array}{l}\text { Note: Results for pooled estimation with fixed effects; fixed effects are small and not presented here. } \\
\text { 1/ Estimation excludes Australian Capital Territory for which skill bias data are not available. } \\
\text { 2/ P-values for the null hypothesis of a coefficient equal to zero are within parentheses. }\end{array}$} \\
\hline
\end{tabular}


Figure 1. Ratio of Real Per Capita State Disposable Income to the Average for Australia (In percent)
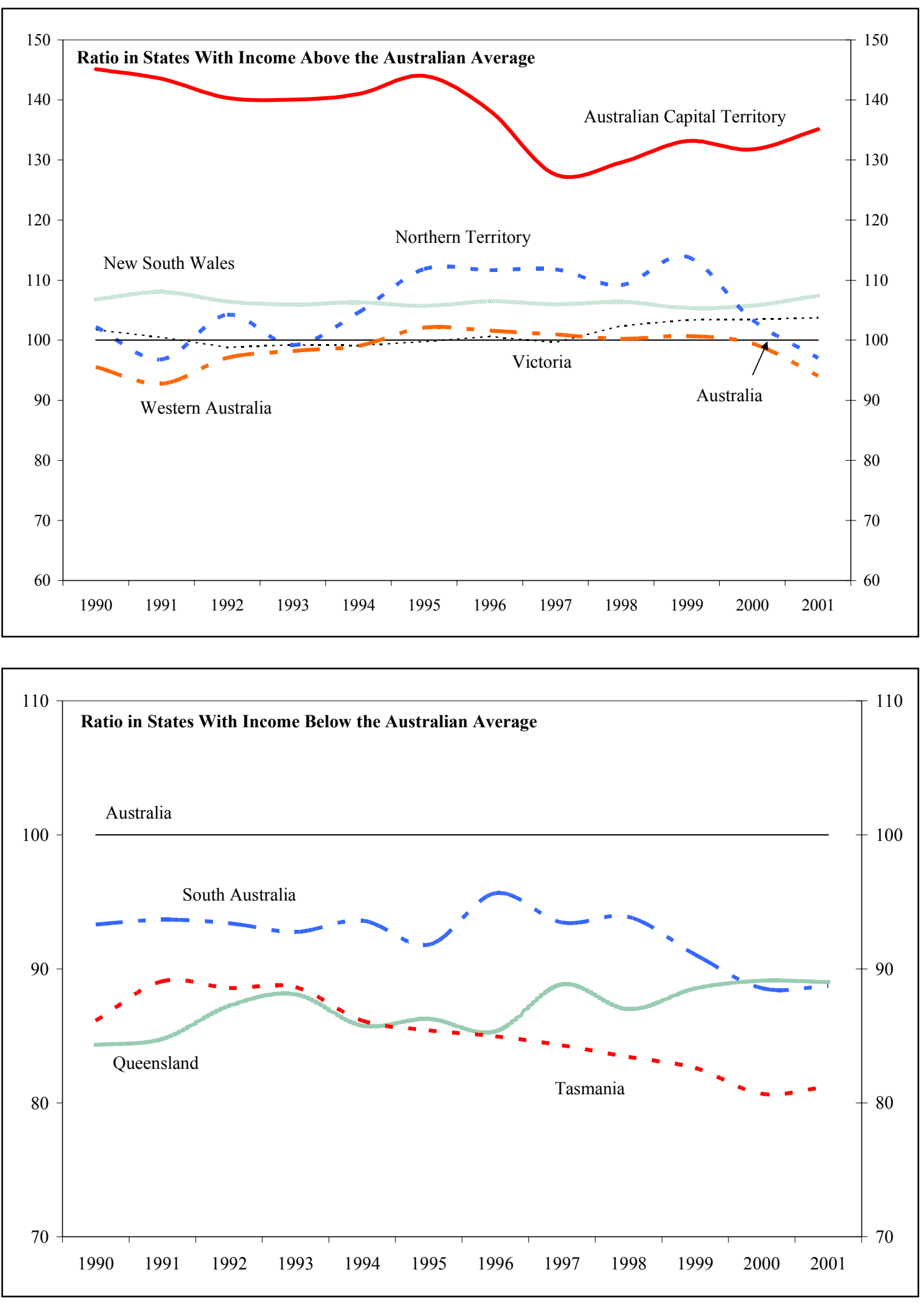
Figure 2. Ratio of Real Per Capita State Output to the Average for Australia (In percent)
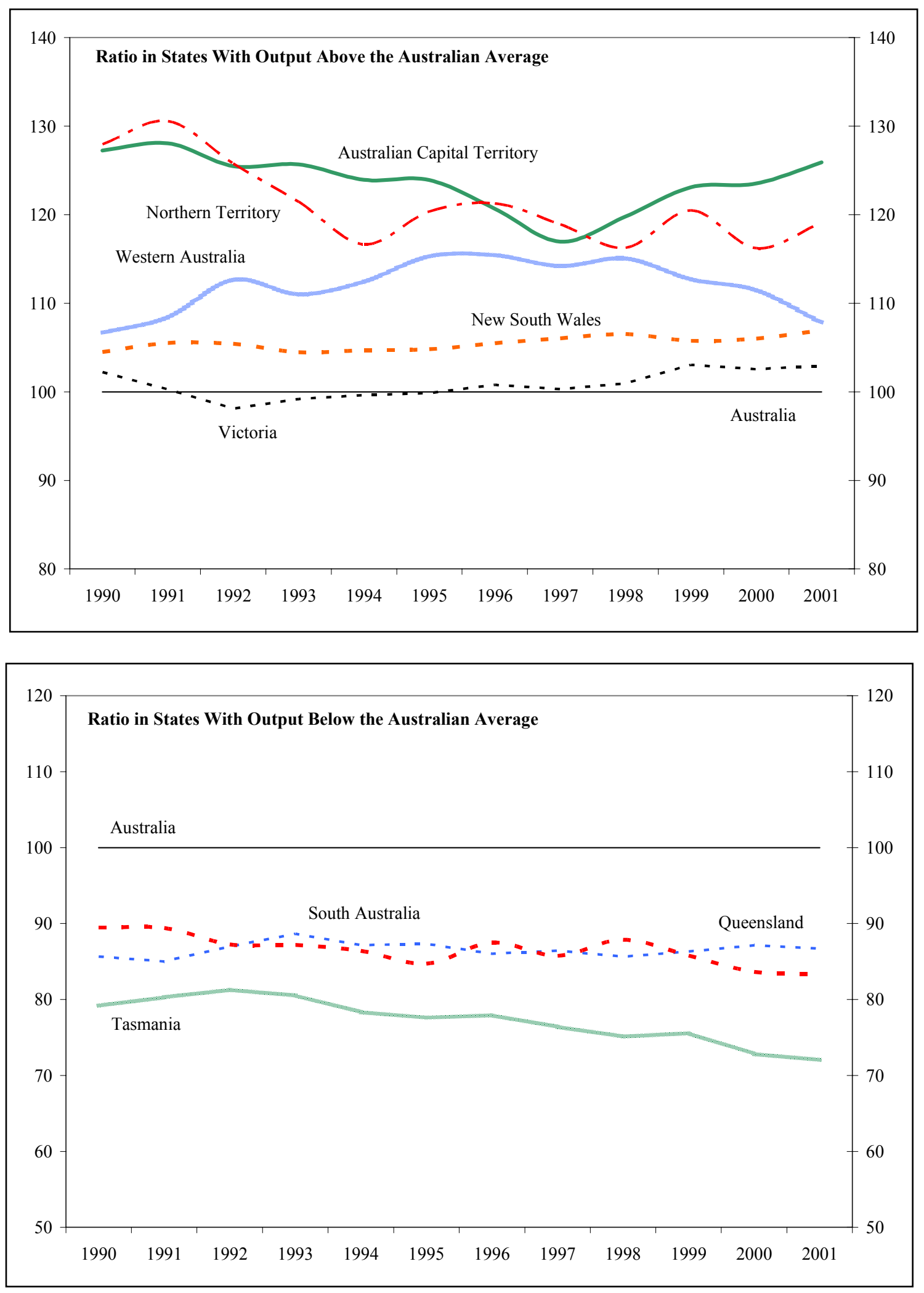
Figure 3. Dispersion of Per Capita State Output and Household Income
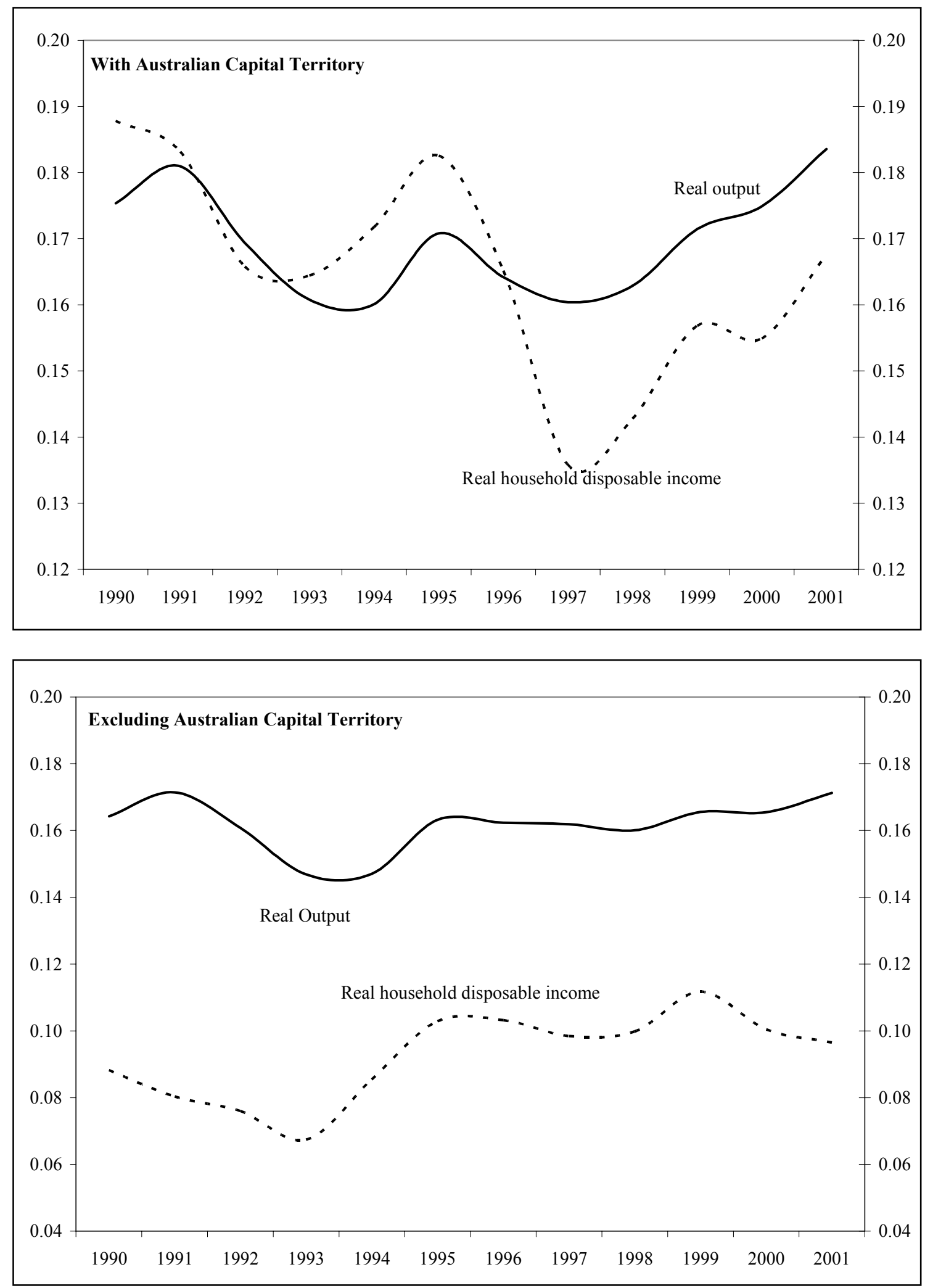

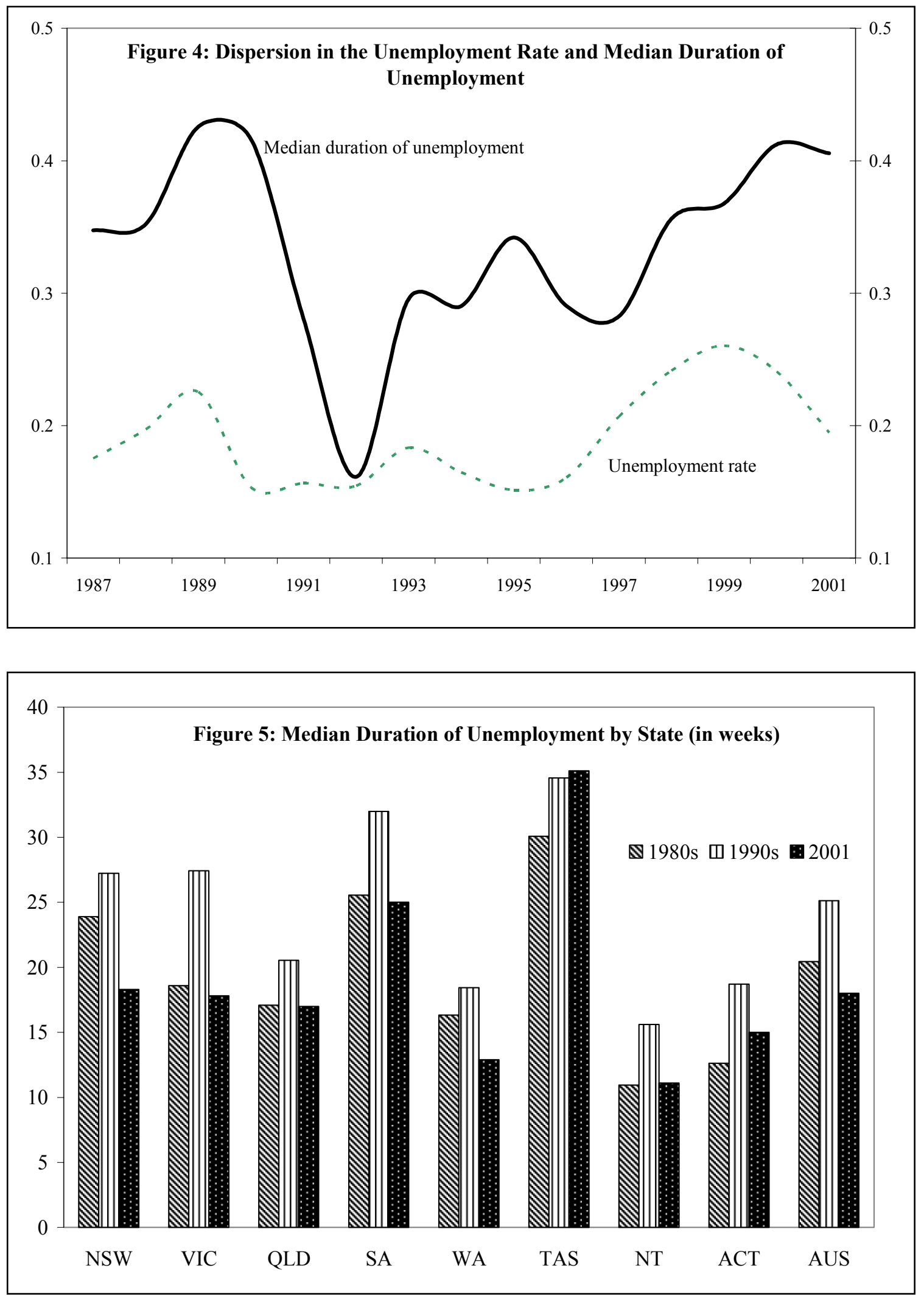
Figure 6. Long-Term Unemployment Rate by State (In percent)

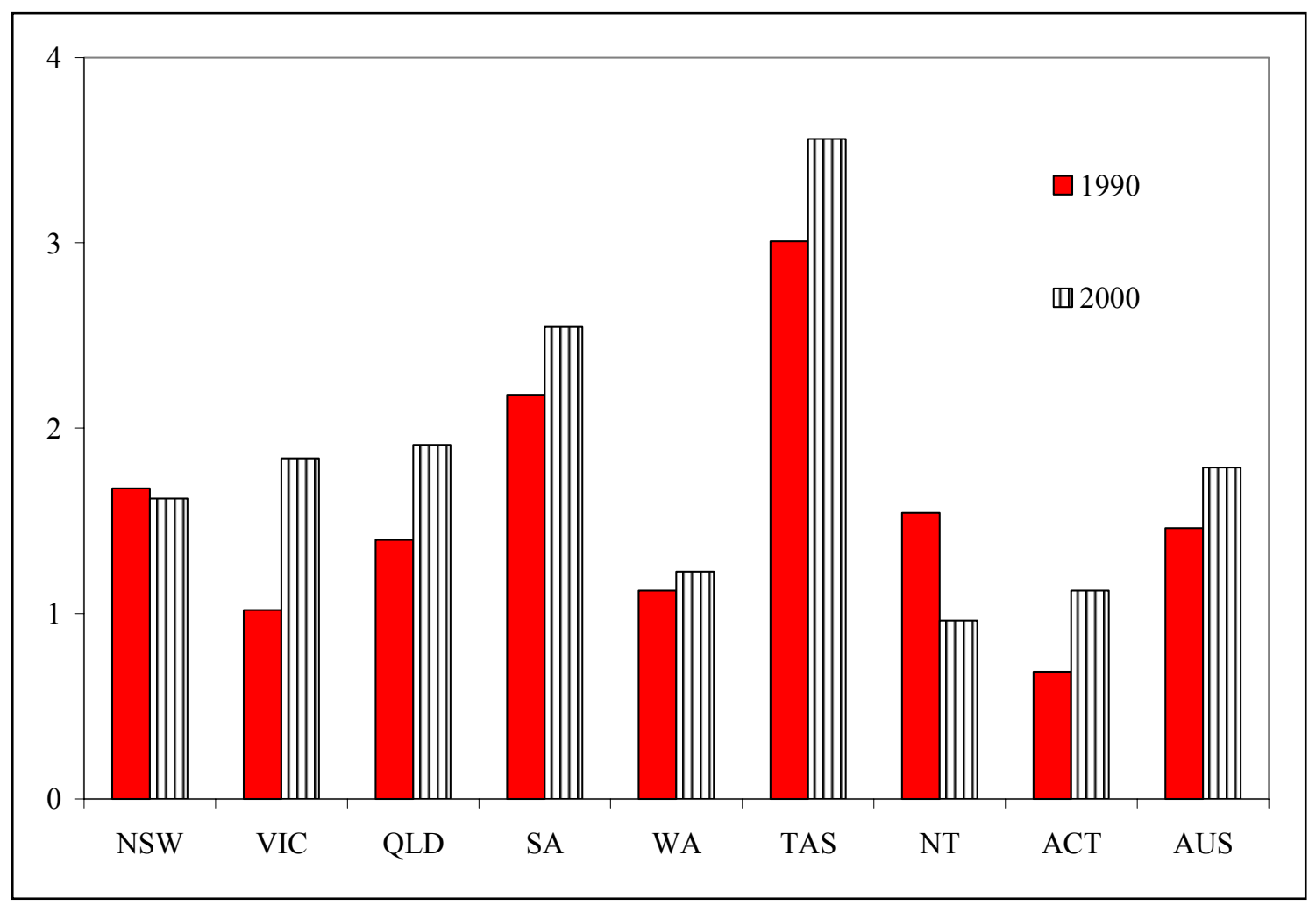


Figure 7. Employment to Population Ratio in Australian States (In percent)
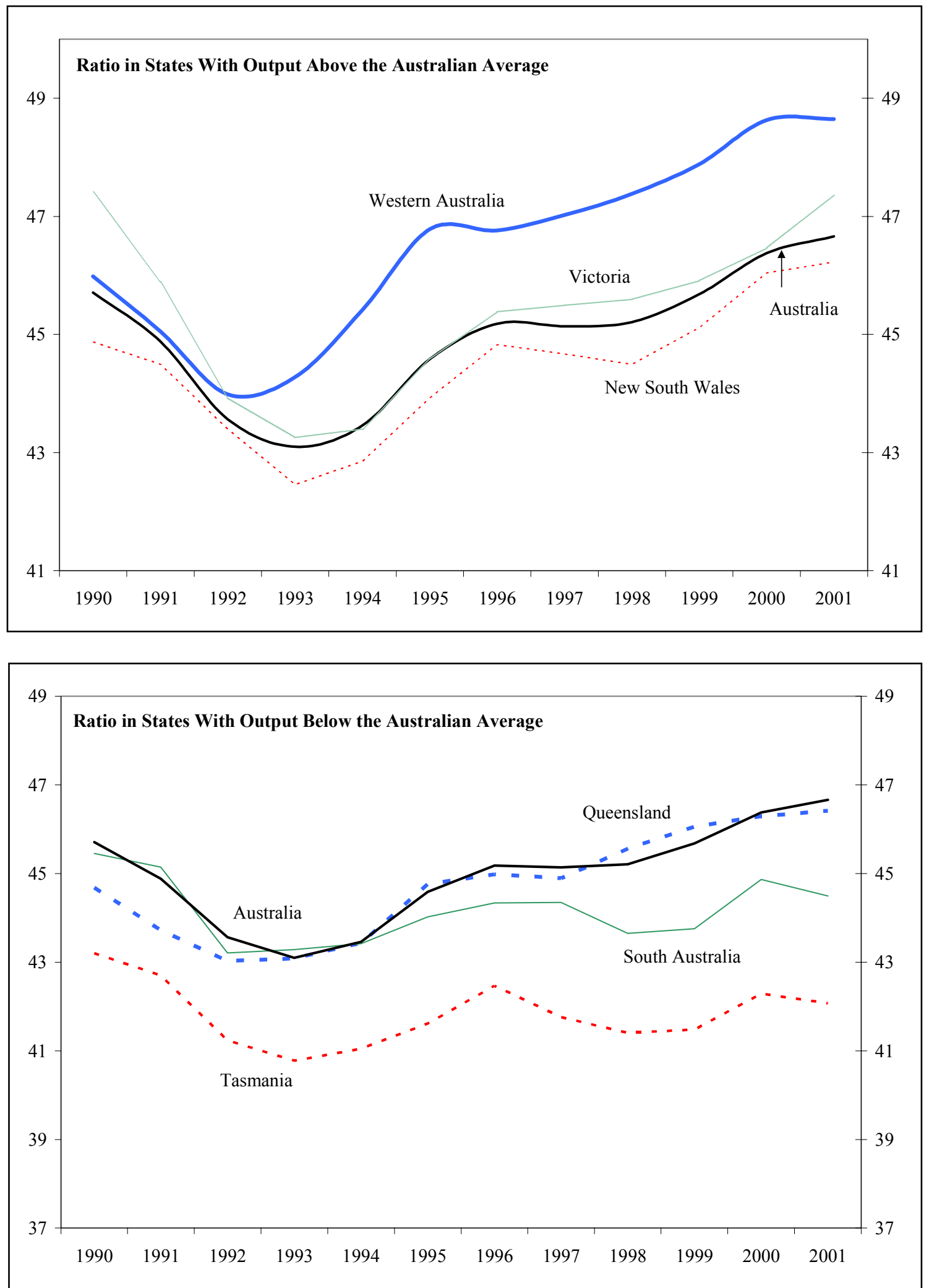


\section{Variables: Definitions and Sources}

Data set: Pooled data for all Australian states and territories for the period 1990-2001. For regressions with the skill bias variable, the Australian Capital Territory has been excluded due to absence of skill data. All nominal variables for states have been converted to real basis using each state's GSP deflator.

Data Sources: Australian Bureau of Statistics, Department of Employment and Workplace Relations, and the Australian Treasury.

$\mathrm{UR}=$ (unemployment rate in state $\mathrm{i}-$ unemployment rate in Australia).

PWGAP $=\ln [($ productivity in state $\mathrm{i}-$ real wage in state $\mathrm{i})$ divided by (productivity in Australia - real wage in Australia], where productivity is output per hour and real wages are average weekly earnings deflated by gross state product deflators.

TRANSFER $=\ln [($ real per capita government transfers to state $\mathrm{i})$ divided by (the national average for real per capita government transfer)], where government transfer is the sum of social assistance and workers compensation from the ABS gross household income data. Old age pension is excluded from the data by applying the ratio of old age pension to total social assistance of the Commonwealth government. The ratio at the Commonwealth level is used due to lack of a similar detailed breakdown of social assistance at the state level. For the unemployment equation, transfers are normalized per labor force participant.

SKILL $=\ln [($ ratio of skill vacancies in state $\mathrm{i}$ to total vacancies in state $\mathrm{i})$ divided by (ratio of skill vacancies in Australia to total vacancies in Australia)].

$\mathrm{DI}=\ln [($ real per capita disposable income in state $\mathrm{i})$ divided by (real per capita disposable income in Australia)].

$\mathrm{DIG}=[(1+$ real per capita disposable income growth in state $i)$ divided by $(1+$ real per capita disposable income growth in Australia)]-1.

GSP $=\ln [($ real per capita gross state product in state $\mathrm{i})$ divided by (real per capita GDP in Australia)].

GSPG $=[(1+$ real per capita GSP growth in state $i)$ divided by $(1+$ real per capita GDP growth in Australia)]-1.

$\mathrm{LG}=[(1+$ labor force growth in state $\mathrm{i})$ divided by $(1+$ labor force growth in Australia $)]-1$.

$\mathrm{KG}=$ real per capita investment in state i divided by real per capita investment in Australia.

$\mathrm{GPP}=\ln [($ real per capita general purpose payments to state i) divided by (average real per capita general purpose payments in Australia)]. 


\section{References}

Australian Government, 1993, "Impediments to Regional Industry," Industry Commission Report No. 35 (Canberra: Government Publishing Service).

Australian Government, 2004, "Commonwealth-State Financial Relations," Budget Paper No. 3, Budget 2004-05.

Buchanan, J., and R. Wagner, 1971, “An Efficiency Basis for Federal Fiscal Equalization,” in Analysis of Public Output, ed. By J. Margolis (Princeton: National Bureau of Economic Research).

Cashin, P., 1995, "Economic Growth and Convergence Across Seven Colonies of Australasia: 1861-1991," The Economic Record, Vol. 71, No. 213, pp.132-44.

, and L. Strappazzon, 1998, "Disparities in Australian Regional Incomes: Are They Widening or Narrowing?” The Australian Economic Review, Vol. 31, No. 1, pp. 3-26.

Craig, J., 1997, “Australia,” in Fiscal Federalism in Theory and Practice, edited by T. Ter-Minassian (Washington: International Monetary Fund).

Debelle, G., and J. Vickery, 1999, "Labor Market Adjustment: Evidence on Interstate Labor Mobility," The Australian Economic Review, Vol. 32, No. 3, pp. 249-63.

Garnaut, R., and V. FitzGerald, 2001, Background Paper, Review of Commonwealth-State Funding, Melbourne.

_ 2002, Final Report, Review of Commonwealth-State Funding, Melbourne.

Harris, P., and D. Harris, 1992, "Interstate Differences in Economic Growth Rates in Australia, 1953-54 to 1990-91", Economic Analysis and Policy, Vol. 22, No. 2, pp. 129-48.

Kaufman, M., P. Swagel, and S. Dunaway, 2003, "Regional Convergence and the Role of Federal Transfers in Canada," IMF Working Paper No. 03/97 (Washington: International Monetary Fund).

Kim, S., 1997, “Economic Integration and Convergence: U.S. Regions, 1984-87,” NBER Working Paper 6335 (Cambridge, Massachusetts: National Bureau of Economic Research).

Lawson, J., and J. Dwyer, 2002, "Labor Market Adjustment in Regional Australia," Reserve Bank of Australia Research Discussion Paper 2002-04, Sydney.

Neri, F., 1998, "The Economic Performance of the States and Territories of Australia: 18611992," The Economic Record, Vol. 74, No. 225, pp. 102-20. 
OECD, 2001, "Innovations to Labor Market Policies: The Australian Way," (Paris: OECD Economic Surveys, Organization for Economic Cooperation and Development).

Productivity Commission, 1999, "Impact of Competition Policy Reforms on Rural and Regional Australia", (Canberra: Australian Government Publishing Service).

Quah, D., 1997, "Regional Convergence Clusters Across Europe,” CEPR Discussion Paper 274 (London: Center for Economic Performance and Research), November.

Wailes, N., and R. Lansbury, 2000, “Collective Bargaining and Flexibility: Australia," InFocus Program on Strengthening Social Dialogue (Geneva: International Labor Organization). 